\title{
Axial Age Heritage in Religious Philosophy and Culture of the Bengal Renaissance*
}

\author{
Tatiana Skorokhodova \\ Penza State University \\ Penza, Russia \\ E-mail: skorokhod71@mail.ru
}

\begin{abstract}
Jaspers' interpretation of a renaissance as recollections and reawakening of the potentialities of the Axial Age is useful methodological approach to the study of cultural ascent epochs in religious, philosophical and social spheres. In British India the Bengal Renaissance XIX - early XX centuries can be described as the creation of 'second Axis' for India - in religious thought and culture. The author proves that the Bengal Renaissance is the result of interaction of two Axial peoples and cultures - Indian and European. The non-trivial synthesis of ideas and values originated from Indian Axis with influences of Christianity and European 'second Axis' culture has generated Bengal religious humanism - the core and the essence of the epoch. Bengal humanism became an intellectual revolution, which had been spread in all spheres of culture and had stimulates social modernization of India.
\end{abstract}

Keywords-Bengal Renaissance; Axial Age; 'second Axis' in India; interaction of Axial peoples and cultures; East-West dialogue; religious humanism; cultural shifts

\section{INTRODUCTION}

An influence of Axial Age heritage on the genesis and development of various renaissances in Axial cultures was marked by Karl Jaspers in 'The Origin and Goal of History'. He wrote on renaissances as recollections and reawakening of the potentialities of the Axial period: "Each new upward flight it returns in recollection to this period and is fired anew by it" in China, India and the West [1]. Jaspers' interpretation of a renaissance as historical and cultural phenomenon is the useful methodological approach to the study of cultural ascent epochs in religious, philosophical and social spheres, in a thought and a practice, and in any post-Axial periods. The approach is especially important for research of the national-cultural renaissances in East-West cultural interactions of Modernity.

The representative example of an appeal to Axial Age heritage is the Indian national-cultural renaissance of XIXearly XX centuries in colonial period [2] [3] [4]. The renaissance embraces different Indian regions and has multiplicity of spheres and aspects. First of regional renaissances was the Bengal Renaissance, which began from religious sphere and developed in social, educational,

*The study is supported by the Russian Science Foundation grant "Indian Philosophy in the History of World Philosophy Context: The Meanings' Translation Problem”, project no. 16-18-10427. scientific, cultural and political spheres [5]. The religious renaissance in Bengal was the core of another renaissance processes; this one in thought and practice was inspired by Axial Age heritage and had influenced on social, intellectual and cultural development of Bengal and, generally, India.

The content of the Bengal Renaissance as well as particularly the religious renaissance was Indian-Western synthesis. Its possibility can be explained by the interaction of two Axial peoples and cultures - Indian and European, which are able to deep mutual understanding and interrelationship. The Bengal Renaissance became the period of origin and development of the East-West cultural interaction in India.

\section{The Bengal Renaissance as the REsponse}

The external challenge of British colonial rule had created the collision between traditional Indian society and modern administration, culture and ways of life, and the creative response had been given by new social and cultural elites inclined to heterodox and adogmatic thinking and nondogmatic practices in social life. Predominantly, it were the representatives of Western-educated stratum (bhadralok), who wished to save, regenerate and develop their traditional cultural heritage along with development of Indian society in Modernity - novations and institutions based on Western knowledge.

British colonial rule had brought in India two-fold Axial European heritage: firstly, it was the Christian Axial Age along with Antiquity; secondly, it were achievements of European the Renaissance, the Reformation, the Enlightenment - which created the foundation of modern developments in the West. In comparison with the West, traditional India was in social, economic and cultural decline, and the new intellectuals understood actual social situation as a crisis, which required an overcoming and a renaissance of society. Bengal intellectuals searched for the grounds for awakening and renaissance in Indian Axial Age - texts, ideas, schools of philosophy, images of ancient past, personalities etc., which had been reconsidered. The creative response to Western challenge began from the appeal to Axial values and ideas reconsidered in dialogue with Western Axial culture.

The Bengal Renaissance can be described as the epoch of creation of 'second Axis' in India - in religious thought and 
culture. On the one hand, the renaissance is the re-birth of ideas and values originated from Axial Upanișads, Bhagavadgita and partially Buddha's teaching. On the other hand, the renaissance was stimulated by an Axial influences of Christianity and European culture. It opened existential resemblance both in goals and in meanings of different religions and cultures. Besides, highest moral and spiritual values of humanism were presented in the foreground in the thought and cultural practice.

A creation of 'second Axis' in Bengal begins in religious thought of first new intellectuals, who have sharp feeling of a gap between old traditional world and new Western civilization and culture. The feeling was a mark of existential crisis alike of Axial one, but in nineteenth century India it was discovery of "the terror of the world and... powerlessness' of old traditions dominated over human and society" [6]. The discovery became possible in comparison with the Other - the Western World - and was realized as religious problem. The condition of traditional society in Bengal and all India - full of power and influence of orthodox Brahmins on Hindu community, as well as orthopraxy and ritualism, superstitions and violent practices such as female infanticide, burning widows alive on husband's funeral pyre (sati), child marriage, polygamy and caste system with its rules and restrictions for human - was realized as the result of religious decline and degradation of Hinduism. But what is Hinduism in its true essence and meaning? Searching for the answer, Bengal intellectuals turns up the foundation of true Hindu faith in Axial heritage of India - its early Upanișads, Bhagavadgita, 'axial-born' Vedanta and Yoga.

\section{FIRST APPEAL TO INDIAN AXIAL AgE: RAMMOHUN ROY}

An appeal to Axial Age in the sacred texts began from Rammohun Roy (1772-1833), who was leading intellectual figure of the epoch and its inaugurator. He had translated five early Upanișads and Badarayana's 'Vedanta-sutra' to Bengali and English, "to convince my countrymen of the true meaning of our sacred books" and "to awaken them from their dream of error: and by making them acquainted with their scriptures, enable them to contemplate with true devotion the unity and omnipresence of Nature's God" [7]. Rammohun selected the ideas 1) of Brahman (Supreme Being) interpreted as Creator, Supporter and Ruler of the universe; 2) rejection of any cause of the world with the exception of God; 3) the need of knowledge of Brahman (jnana), devotion (bhakti); 4) "command over our passions and over the external senses of the body and good acts" for 'eternal beatitude' for all human beings, and 5) a rejection of Brahminical rules and rites as obligatory for all classes of Hindu [8]. Then Rammohun had interpreted selected Upanișadic ideas in his own mode, creatively developing basic meanings and implanting in them other ones from European Axial heritage.

Owing to Upanișads, Rammohun had discovered the monotheism in Hinduism and had called to a worship One God (Supreme Being). The philosopher explained, that a plurality of Vedic gods intended "for the sake of those whose limited understandings rendered them incapable of comprehending and adoring the invisible Supreme Being" [9]. Thus, Rammohun have actualized high Axial goals faith and knowledge of Absolute (Brahman), universal spiritual vertical between a soul and God, which is basic meaning of values - from soteriological and liberation to "comfort and happiness" (R. Roy). Rammohun's intellectual work is the construction of high religion in Hinduism's context, based on universal faith for all society. Along with the religion he had created new religious thought in India.

From sharp critics of polytheism, ritualism and idolatry in Hindu society Rammohun came to discovery of human personality and its value. The "erroneous conceptions" on Scriptures and gods leads Hindus to "to self-destruction, or to the sacrifice of the lives of their friends and relations", but a situation could be changed by right relations to human [10]. Being a God's creature, human possessed moral faculties, which "a capability of almost boundless improvement" [11]. The high destination of a man to serve God and other men requires knowledge of his life's value and differentiation of good and evil in the world. Therefore, Rammohun renovates 'Axial vertical' 'Brahman-Atman' in the form 'God human being', based on human equality and a general pursuit to eternal beatitude. Regardless of a social status, a salvation can be gained by each human through the faith, the knowledge of God and righteous life. The vertical by Rammohun creates the vectors of thinking on human earthly life and ethics as well as on individual eschatology. In so far as God by Rammohun is ethical Being, ("He has from eternity been assigning to all creatures their respective purposes"), the pursuit of human to eternal beatitude must be put in equilibrium by 'spiritual horizontal' - ethical relations with the world, first of all social one [12].

A creation of new ethics in the early Bengal Renaissance founded on two Axial religious values - Upanișadic and Christian. Influenced by Christian scriptures, Rammohun said: "If religion consists of the blessings of self-knowledge and of improved notions of God and his attributes and [if] a system of morality holds a subordinate place, I certainly prefer the Vedas. But the moral precepts of Jesus are something most extraordinary. The Vedas contain the same lessons of morality but in a scattered form" [13]. Rammohun proposes Christ's precepts to Hindus as best moral precepts. Philosopher tried to destruct traditional ethics of Hindus, connected with caste rules, restrictions and punishment for ritual impurity. "Murder, theft, or perjury, though brought home to the party by a judicial sentence, so far from inducing loss of caste, is visited in their society with no peculiar mark of infamy or disgrace" [14]. Briefly, Rammohun's ethics is natural continuation of religion, it is to follow high values of love and mercy and moral precepts, to make good deeds, to reject of selfish mind and to consider a sin as evil against the neighbor. In Introduction to translation of 'Isa-upanișad' Rammohun had integrated ethic 'golden rule': Hindus' mind must imbibe "a complete perception and practice of that grand and comprehensive moral principle Do unto others as ye would be done by" [15]. Besides, Rammohun's idea of mercy and compassion in social life had created Bengal religious humanism. 
Rammohun Roy, his younger contemporaries and spiritual heirs had opened the self-value and dignity of human as a person and independent subject. Unlike of European the Renaissance humanists who sought for human right of happiness, Bengal thinkers built their humanism from an idea of human suffering. From the works by Rammohun in defense of monotheism and against sati, humanism was founded on the idea of compassion for victims of social order, religious customs and prejudices, of economic system and political constraints. He wrote: "A feeling for the misery and distress of his fellow creatures is, to every one not overpowered by selfish motives, I presume, rather natural than optional. ... A sense of the duty which one man owes to another, compels me to exert my utmost endeavors to rescue them from imposition and servitude, and promote their comfort and happiness" [16]. From Axial Age Indian thought dealt with questions on suffering - as a part of cosmic order and characteristic of human life and its overcome, and saw in that a result of individual efforts. In Europe the idea of compassion and mercy for a human is archetype, including its social aspect. Rammohun was a first who had seen an indifference to human's suffering in Hindu society and he had apprehended it as social evil, generated from moral and religious decline. As he wrote on sati, "seeing the women thus dependent and exposed to every misery, you feel for them no compassion, that might exempt them from being tied down and burnt to death" [17].

Two Axial cultures were united in Rammohun's humanism: Christian ethics and imperative of social compassion and an ideal of perfect human - and reconsidered Indian idea on human misery in the world. This synthesis helped him to prove for his own compatriots that a society with callousness towards human, his life and fate is antihuman. Thus, Rammohun has switched the theme of suffering from metaphysical to social-and historical area. Hence, Bengal thinkers and reformers from Rammohun Roy and Iswarchandra Vidyasagar to Keshubchandra Sen and Swami Vivekananda saw in the relief of sufferings the main condition for achievement of happiness.

\section{REligious Humanism AND CULTURAL SHIFTS}

Rammohun's religious humanism was mighty stimulus to reconsideration of actual social order, especially its orthodoxy, ritualism, immorality and different kinds of violence - from psychological to physical, especially in regard to women [18]. Moreover, I propose to consider the birth of Bengal humanism as immediate result of an appeal to Axial ideas both Indian and European, as well as, generally, the core and the essence of the Bengal Renaissance. Being the elitist phenomena of the philosophy and culture, Bengal religious humanism became the intellectual revolution, which had been spread in all spheres of culture and had stimulates social modernization of India [19]. Now, I try to demonstrate how religious-philosophical ideas are embodied in cultural practice and stimulated cultural shifts.

- The idea of universal God (Brahman/Absolute) who is Creator of the universe and a human. The idea is basic in Bengal religious philosophy and has been inspired by Upanișadic idea of Brahman as ekamevadvitiyam (one without second, 'Chandogya.upaniśad', IV, 21) as well as Biblical notion of GodCreator. Synthesis of two axial ideas helped to connect with Reality both human existence in the world and social life in history - by putting in foreground peripheral Upanișadic idea of Creator ('Mundaka-upaniśad'. I.1) and accenting His ethical character. Apart from religious sphere, the idea of monotheism became basic for development of NeoVedanta philosophy from Rammohun's works to Swami Vivekananda, Aurobindo Ghose and others. The thinkers turned to orthodox theistic darśanas which recognize the Vedas authority and followed tradition; but they synthesized in Neo-Vedanta its three branches (advaita, visistādvaita, dvaita) and implement into one - rationally of intuitively - some ideas of European Renaissance, the Reformation and the Enlightenment.

For example, Swami Vivekananda had integrated in his lectures three branches of the Vedanta as three stages on the way of knowledge of Brahman, and said, on traditional means to comprehend God - the work (karma), the knowledge of self and nature (raja), the philosophy (jnana) and love (bhakti) [20]. But he also reiterated Rammohun's idea of social service: "What vain gods shall we go after and yet cannot worship the god that we see all round us, the Virât? ... What is needed is Chittashuddhi, purification of the heart. And how does that come? ... The first of all worship is the worship of the Virât - of those all around us. ... These are all our gods - men and animals; and the first gods we have to worship are our countrymen" [21].

In philosophy of Rabindranath Tagore the idea of universal God-Creator had been developed in conception of jivan-devata (God-Life) in his poetry and of 'Religion of Man' as creative subject. Besides, the idea of God's universality creates a dialogue of religion (Hinduism, Islam, Christianity) in consciousness of thinkers and enrichment of reformatory practice.

- The idea of Hinduism as religion of high faith and love which inspired by reflections on the essence of religion and its form and matter balance. Answering to the questions on true essence of Hindu religion, its practices and mode of worship and social doctrines, Bengal thinkers and reformers had created two images of Hinduism and had proposed two practices of worship. Rammohun Roy and his adherents had presented Hinduism as monotheistic faith, prescribed by Vedas or, more correctly, early Upanișads and had founded in 1828 the Brahmo Samaj “... as and for a place of public meeting of all sorts and descriptions of people without distinction as shall behave and conduct themselves in an orderly sober religious and devout manner for the worship and adoration of the Eternal Unsearchable and Immutable Being who is the Author and Preserver of the Universe..." [22]. 
Inspired by Christian - first of all Unitarian congregational worship, Brahmo Samaj became in Bengal circumstances special monotheistic movement in the epoch, which had brought up several generations of reformers, scientists, politics and literary men [23]. Another spiritual movement was Neo-Hinduism inspired firstly by Bankimchandra Chattopadhyay and Swami Vivekananda. According to Vivekananda, Hinduism as ""the mother of religions" "does not consist in struggles and attempts to believe a certain doctrine or dogma, but in realizing - not in believing, but in being and becoming" based on the Vedas' revelation, Hinduism embraces all forms of faith "from the high spiritual flights of the Vedanta philosophy... to the low ideas of idolatry with its multifarious mythology, the agnosticism of the Buddhists, and the atheism of the Jains, each and all have a place in the Hindu's religion", but the essence of Hinduism is monotheistic faith in "the pure and formless One, the Almighty and the All-merciful" and in worship Him through love [24] [25]. Besides, owing to Bengal philosophers had represented Hinduism to the world as religion of love, tolerance, humanistic faith and self-denying for other people. The Modern idea of Hinduism in the world predominantly, based on the Indian Renaissance's image of one.

- Moral values and duties postulates as the main motive of spiritual and social life, therefore, the main intention of religious thinkers is a cultivation and development of moral consciousness and behavior of their contemporaries. New normative ethics was formed on the interpretations of ethics (goodness) and morals (duty) from Upanișads, Bhagavadgita and dharmașastras (Manu etc). Devendranath Tagore collected normative rules from Manusmriti and Mahabharata to his 'Brahma Dharma Grantha' ('The book of Brahma Dharma') and proposed relation to fellow as God and rejected all form of violence [26]. Another leader of the Brahmo Samaj Keshubchundra Sen grounds moral duties from Christian notion of sin. Self-sacrifice for improvement of both personality and social life is main idea in K. Sen's ethics [27]. Neo-Hindu ethics proposes the interpretation of Hindu dharma as morality, righteousness, right behaviour and justice, and connects it with development of human [28].

Axial synthesis in both images of ethics was an impulse of social reformist activity and development of moralizing in modern Bengal literature and theatre. Originated from collision between moral norms and real behavior of human, idea of existence of social problems in society had born the fight of Bengal reformers against caste and gender inequality, different forms of discrimination for removing the traditional dogmas and rules and injustice in a society.

Based on newborn normative ethics, Brahmos and Neo-Hindus, writers and dramatists represent a social evils and problems (novel by Pearychand Mitra
'Alaler Gharer Dulal', social novels by Bankimchandra Chattopadhyay etc.), and victims of social circumstances and in such a manner propose to reflect and to resolve conflicts in social life.

- A discovery of personality as spiritual, moral, cultural and creative human being reflects two Axial meanings in synthesis: Indian unity of atman and Brahman or, by Jaspers' words, 'in the knowledge of his self and the world as atman' along with imported from Europe "the conscious inwardness of personal selfhood" of the Renaissance and the Enlightenment [29]. The complex of personalistic ideas in the religious philosophy of Modern Bengal embraces wide range of ideas from human right to liberty, freedom and happiness - to deliverance from sufferings, as well as to freedom of thought, free development and a priority of reason in life. For Swami Vivekananda the greatness of human had determined by his own divine nature: "The living God is within you, and yet you are building churches and temples and believing all sorts of imaginary nonsense. The only God to worship is the human soul in the human body. Of course all animals are temples too, but man is the highest, the Taj Mahal of temples. If I cannot worship in that, no other temple will be of any advantage. The moment I have realized God sitting in the temple of every human body, the moment I stand in reverence before every human being and see God in him - that moment I am free from bondage, everything that binds vanishes, and I am free" [30]. Rabindranath Tagore had created fullfledged philosophy of personality as creative being who is able both be co-creator of God and gain his wholeness in other peoples. From personalistic idea had grown the Bengal enlightenment activity in educational, scientific and cultural spheres, the social service and a defense of human social, economic, political and cultural rights, cultural life and artistic creativity in literature, fine arts and music.

- The idea of renaissance, or awakening in society appeared firstly in reflections of Rammohun Roy: 'I began to think, that some similar to European renaissance might have taken place here in India' [31] His spiritual inheritors developed an idea of renaissance as overcome of the present decline in society and development in present and future. Krishnamohun Banerjea said: "...We are by no means satisfied with the state of things around us. We wish we were not surrounded with wretched and degraded fellowmen and that ourselves could boast of wiser and more perfect heads and were inspired by a stronger public spirit" [32]. Bengal thinkers saw the source for the renaissance both in discovery and imbibing of European ideas, norms and institutions (including Christian values - as Krishnamohun Banerjea proposed) and in reconsideration and renovation of ancient traditions (Axial in the essence) - by removing of its latter additions. The idea had born a discovery of Indian past by Indians themselves, 
the creation of new historical consciousness with an orientation to future and development of historical science. Surendranath Banerjea said: "...If you seriously wish to regenerate your country, wish to see her great and prosperous, then you must have a thorough knowledge of the evils that beset her, the miseries that afflict her. First learn the disease, before you minister to the patient. But the miseries that afflict of India, the disease she is suffering from, are not the work of a day. Their roots stretch back into remote past. The past must be studied, before the work of Indian regeneration could be accomplished" [33]. Moreover, the renaissance idea itself has Axial character as reflections on existential and social crisis to searching of ways of regenerations in intellectual project of a development of Indian society.

\section{CONCLUSION}

The synthesis of Axial Age ideas from Indian and European Axes in Bengal religious thought admits saying on a creation of 'Second Axis' in India. A discovery of the Other Axial culture means for India the beginning of multifold free communications with the world as well as the discovery of her own Axial heritage in the history. Reconsideration of both Axial heritages in the light of traditional-modernity conflict born religious and intellectual revolution in elite's consciousness. Notwithstanding the elitist character of the revolution, its main vectors were the creation of non-traditional modern consciousness, the beginning of social and cultural modernization and the birth of modern creative persons who able to novation and synthesis of native and universal in thought and work.

The Bengal Renaissance as the time of Indian Second Axis had achieved two general results. For India it were the modern shifts in religious, social and political spheres breakthroughs of personal inner religion, social compassion and justice, human rights and freedom, social activity for future, the creation of national literature, theatre, fine arts, music by distinguished authors etc. For the world, it were the creation of attractive image of Indian culture and philosophy as well as the image of Hinduism as one of world religions religion of humanity, tolerance, love and high spirit. The heritage of the Bengal Renaissance thought is an example of positive decision of the East - the West problem by Asian people through building of living and dynamic dialogue between Axial civilizations, religions and cultures. Today his heritage is the important 'conservative' force in opposing to fundamentalism, extremism, xenophobia and aggression.

\section{REFERENCES}

[1] Karl Jaspers, The Origin and Goal of History. Translated by M. Bullock. 3rd ed. New Haven, L.: 1965, p. 7.

[2] Subrata Dasgupta, Awakening: the Story of the Bengal Renaissance. Noida: Random House Publishers, 2010.

[3] Subrata Dasgupta, The Bengal Renaissance: Identity and Creativity from Rammohun Roy to Rabindranath Tagore. Delhi: Permanent Black, 2012.
[4] D. Kopf, British Orientalism and Bengal Renaissance. Berkeley: University of California Press, 1969.

[5] Tatiana G. Skorokhodova, The Bengal Renaissance: Essays on History of Socio-cultural Synthesis in Modern Indian Philosophical Thought. St.-Petersburg: St. Petersburg Centre for Oriental Studies Publishers, 2008. (In Russian).

[6] Karl Jaspers, The Origin and Goal of History, p. 7

[7] Raja Rammohun Roy, The English Works / Ed. by J.C. Ghose. In 4 vols. New Delhi: Cosmo, 1982, Vol. I, pp. 3, 5.

[8] Ibid., p. 14

[9] Ibid., p. 36.

[10] Ibid., p. 35 .

[11] Ibid., p. 73

[12] Ibid., p. 76.

[13] Amlan Datta. Religion and Rationalism: Road to Emancipation // Raja Rammohun Roy and the New Learning. Raja Rammohun Roy Memorial Lectures. Ed. by B. P. Barua. Calcutta: Orient Longman, 1988, p. 93-100.

[14] Raja Rammohun Roy, The English Works, Vol. I, p. 74.

[15] Ibid.

[16] Ibid., p. 35

[17] Ibid., Vol. II, p. 363.

[18] Subrata Dasgupta, Awakening: the Story of the Bengal Renaissance, pp. 112-124, 221-229, 277-318.

[19] Subrata Dasgupta, The Bengal Renaissance: Identity and Creativity from Rammohun Roy to Rabindranath Tagore, pp. 2-7.

[20] Swami Vivekananda. Complete Works. Mayavati Memorial Edition. 12th ed. 9 vols. Mayavati-Almora: Advaita Ashrama, 1998-2002, Vol. III, pp. 70-71.

[21] Ibid., pp. 300-301.

[22] Raja Rammohun Roy, The English Works, Vol. I, p. 216.

[23] D. Kopf, Brahmo Samaj and Making of Modern Indian Mind. Princeton: University Press, 1979.

[24] Swami Vivekananda. Complete Works, Vol. I, p. 3

[25] Ibid, pp. 6, 11.

[26] Devendranath Tagore, The Autobiography. Transl. from Original Bengali by S. Tagore and I. Devi. Calcutta: S.C. Lahiri \& Co., 1909, pp. 83-84.

[27] Keshub Chunder Sen, Lectures in India. Calcutta: Navavidhan Publishing Committee, 1954, pp. 272-292.

[28] Bankim's Hinduism. An Anthology of Writing by Bankimchandra Chattopaddhyay. Ed. by Amiya P. Sen. New Delhi, Permanent Black. 2011, pp. 147-148, 155-156.

[29] Karl Jaspers, The Origin and Goal of History, pp. 7, 63.

[30] Swami Vivekananda. Complete Works, Vol. II, p. 321.

[31] George Smith, Life of Alexander Duff, Vol. 1-2. New York: A. C. Armstrong \& Sons. 1879, Vol. I, p. 118

[32] Awakening in Bengal in the Early Nineteenth Century. Selected Documents. Ed. by G. Chattopadhyaya. Calcutta: Progressive Publishers. 1965, p. 11.

[33] Surendranath Banerjee. The Study of Indian History // Nationalism in Asia and Africa. Ed. by Elie Kedourie. N. Y., Cleavland, L.: Widenfield, 1970. P. 225-244. 